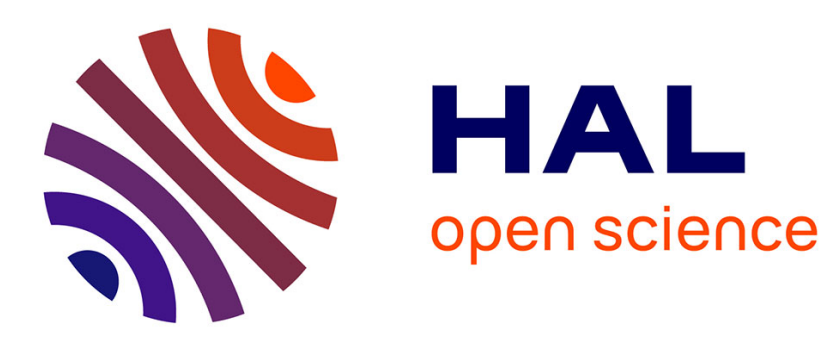

\title{
EXAFS and XANES Study of Structural and Electronic Changes in Y1-xPrxBa2Cu3O7
}

\author{
M. Khaled, N. Saini, S. Gurman, J. Amiss, K. Garg
}

\section{To cite this version:}

M. Khaled, N. Saini, S. Gurman, J. Amiss, K. Garg. EXAFS and XANES Study of Structural and Electronic Changes in Y1-xPrxBa2Cu3O7. Journal de Physique IV Proceedings, 1997, 7 (C2), pp.C2-1121-C2-1122. 10.1051/jp4:19972153 . jpa-00255216

\section{HAL Id: jpa-00255216 https://hal.science/jpa-00255216}

Submitted on 1 Jan 1997

HAL is a multi-disciplinary open access archive for the deposit and dissemination of scientific research documents, whether they are published or not. The documents may come from teaching and research institutions in France or abroad, or from public or private research centers.
L'archive ouverte pluridisciplinaire HAL, est destinée au dépôt et à la diffusion de documents scientifiques de niveau recherche, publiés ou non, émanant des établissements d'enseignement et de recherche français ou étrangers, des laboratoires publics ou privés. 


\title{
EXAFS and XANES Study of Structural and Electronic Changes in $\mathrm{Y}_{1-x} \mathrm{Pr}_{x} \mathrm{Ba}_{2} \mathrm{Cu}_{3} \mathrm{O}_{7}$
}

\author{
M. Khaled, N.L. Saini, S.J. Gurman*, J.C. Amiss** and K.B. Garg \\ Department of Physics, University of Rajasthan, Jaipur 30 2004, India \\ * Department of Physics and Astronomy, University of Leicester, Leicester LE1 7RH, UK \\ ** Biomedical Sciences, Sheffield Hallam University, Sheffield SI IWB, UK
}

\begin{abstract}
We present X-ray absorption fine structure (EXAFS) data from Y,Pr,Ba and Cu edges for various concentrations of $\mathrm{Pr}$ in $\mathrm{Y}_{1-\mathrm{x}} \mathrm{Pr}_{\mathrm{X}} \mathrm{Ba}_{2} \mathrm{Cu}_{3} \mathrm{O}_{7}$. Analysis of $\mathrm{Y} \mathrm{K}$-edge EXAFS shows no evidence for major changes in interatomic distance or in its mean square variation with composition. The individual $\mathrm{Ba}-\mathrm{O}$ distances have weak compositional dependence. The Pr$O$ distance is found to vary linearly with composition. We have interpreted the changes in Pr-O distance to conclude the existence of $\mathrm{Pr}$ in a mixture of $\mathrm{Pr}^{3+}$ and $\mathrm{Pr}^{4+}$ states. The $\mathrm{Cu}-\mathrm{O}$ coordinates at about $2.4 \AA$ (the apical oxygen for $\mathrm{Cu}$ ) appear to have a compositional dependence. Changes in electronic structure are also discussed besides structural changes along with their correlation.
\end{abstract}

\section{INTRODUCTION}

Amongst all the rare-earth 1-2-3 copper oxide compounds, $\mathrm{PrBa}_{2} \mathrm{Cu}_{3} \mathrm{O}_{7}$ stands out $:$ it is NOT a superconductor! Also if $\mathrm{Pr}$ is substituted for $\mathrm{Y}$ in the classic 1-2-3 superconductor $\mathrm{YBa}_{2} \mathrm{Cu}_{3} \mathrm{O}_{7}$ then the transition temperature steadily falls and the material remains an insulator for Pr contents greater than 0.55 . There is no change in crystal symmetry with increasing Pr content, and only very small changes in the size of the unit cell and yet the superconductivity disappears. The reasons for this are not known.

Several models have been proposed for the suppression of superconductivity by $\mathrm{Pr}$. If it exists as $\mathrm{Pr}^{4+}\left(\mathrm{Y}^{3+}\right)$ then there will be a progressive filling of holes as the Pr content increases. However, crystal field studies suggest that Pr is $3+$ in these materials. $\mathrm{Pr}^{3+}$ could act as magnetic pair-breaker, which would suppress $\mathrm{Tc}$, but this does not explain the transition to an insulating state [1].

\section{EXPERIMENTAL DETAILS}

We have used X-ray absorption spectroscopy to investigate both the structure around, and the valence of, the cations in samples of $\mathrm{Y}_{1-\mathrm{x}} \mathrm{Pr}_{\mathrm{x}} \mathrm{Ba}_{2} \mathrm{Cu}_{3} \mathrm{O}_{7}$ with $\mathrm{x}$ varying from 0 to 1.0. Since EXAFS is a local probe we can investigate each cation environment independently by measuring its absorption edge structure. The XANES on each edge also gives information on the charge state of each cation. All four cations were investigated using the $\mathrm{Y}$ and $\mathrm{Cu} \mathrm{K}$-edges and $\mathrm{Ba} \mathrm{L} 3$ edge. Because of the problems with overlapping edges, the $\operatorname{Pr} \mathrm{L}_{2}$ edge was used for that cation. Good data were obtained in transmission mode for all four edges using stations 7.1 and 9.2 of the SRS, Daresbury. The EXAFS was analyzed using EXCURV92 with inclusion of multiple scattering.

\section{RESULTS AND DISCUSSION}

Results for the close oxygen neighbours of the $\mathrm{Y}$ and Ba cations are shown in Table 1.

Table 1. (Uncertainty on $R \pm 0.002 \AA$ )

\begin{tabular}{|c|c|c|c|c|}
\hline \multirow{2}{*}{$\mathrm{x}$} & \multicolumn{2}{|c|}{$\mathrm{Y}-\mathrm{O}$} & \multicolumn{2}{|c|}{$\mathrm{Ba}-\mathrm{O}$} \\
\cline { 2 - 5 } & $\mathrm{R}(\AA)$ & $\sigma^{2} 10^{-4} \AA^{2}$ & $\mathrm{R}(\AA)$ & $\sigma^{2} 10^{-4} \AA^{2}$ \\
\hline 0.0 & 2.36 & $65 \pm 10$ & 2.80 & $175 \pm 25$ \\
0.2 & 2.35 & $75 \pm 25$ & 2.80 & $150 \pm 20$ \\
0.4 & 2.35 & $75 \pm 15$ & 2.77 & $200 \pm 25$ \\
0.6 & 2.36 & $50 \pm 5$ & 2.80 & $160 \pm 20$ \\
0.8 & 2.36 & $65 \pm 10$ & 2.79 & $150 \pm 15$ \\
1.0 & & & 2.79 & $170 \pm 20$ \\
\hline
\end{tabular}

There are no variations in the $\mathrm{Y}-\mathrm{O}$ and $\mathrm{Ba}-\mathrm{O}$ parameters, except for very small increase in distance with increasing $\mathrm{x}$ in line with the increasing lattice constant. Figure 1 shows the $\operatorname{Pr} \mathrm{L}_{2}$ fit results for the close oxygen neighbour for different $\mathrm{Pr}$ concentrations and the mean square variations are shown in Figure 2. There is a significant variation in the Pr-O parameters. At low Pr concentration the Pr-O distance is short and goes on increasing with increase in Pr concentration. We find Pr-O at 


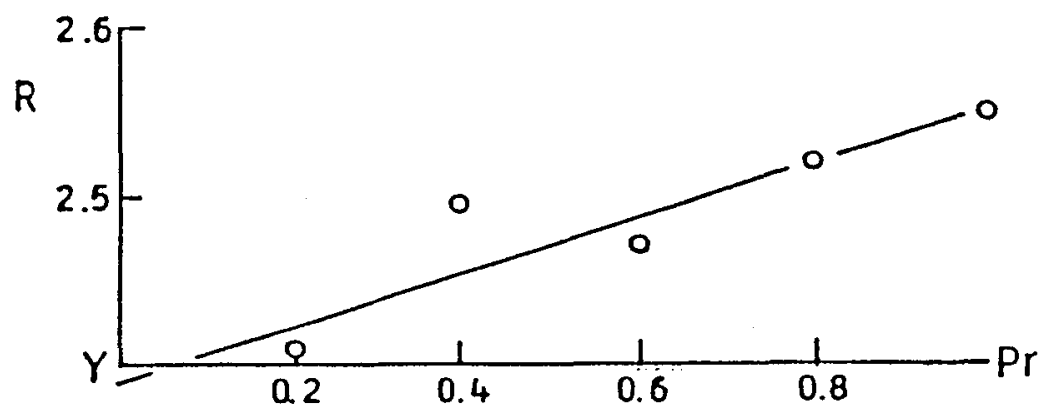

Fig. 1. Pr $\mathrm{L}_{2}$ edge. Pr-O distances for different Pr concentrations.

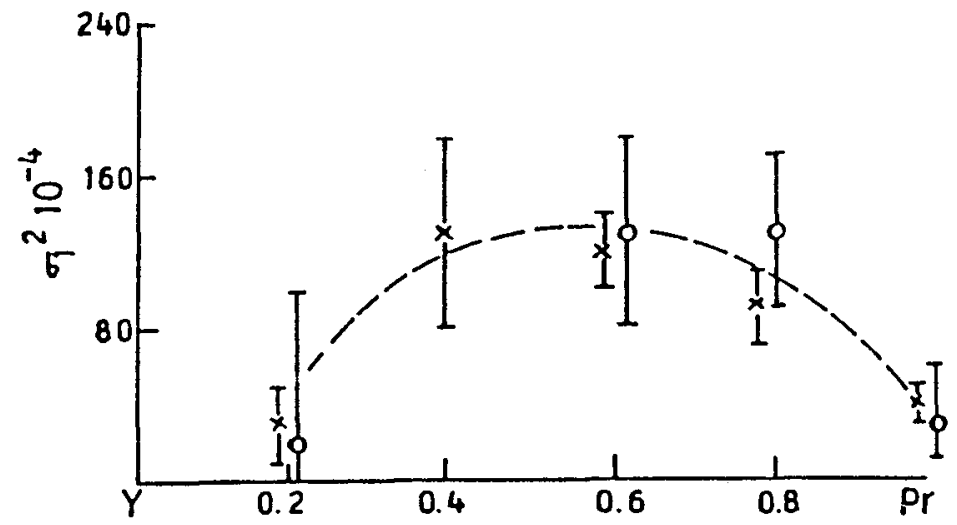

Fig. 2. $\operatorname{Pr} \mathrm{L}_{2}$ edge. Pr-O mean square variation for different concentrations. o when $\mathrm{N}$ floating, $\mathrm{x}$ when $\mathrm{N}$ fixed.

$(2.39 \pm 0.16 \mathrm{x}) \AA$ with a Debye-Waller factor $(40 \pm 350 \mathrm{x}[1-\mathrm{x}]) \cdot 10^{-4} \AA^{2}$. This implies the presence of TWO Pr-O distances and a distortion of the oxygen layer close to the $\mathrm{CuII}$ atom. The mean square variation in Pr-O is $\mathrm{x}$ dependent, peaking around $x=0.5$ and is higher than the constant value of $Y-O$. This suggests some constraints in the $O$ layer. The fact that the $\sigma^{2}$ is smaller and constant for Y-O and varies for Pr-O suggests that the $\mathrm{Y}-\mathrm{O}$ is strong. We interpret the data in terms of existence of Pr in two valence states at two different sites : at low Pr concentration where the Pr-O is short, Pr exists both in trivalent and tetravalent states at $\mathrm{Y}$ site (rare-earth site) while at higher concentration the trivalent $\mathrm{Pr}$ is dominating (Pr-O large and a decrease in mean square variation) and occupies $\mathrm{Ba}$ site which is more favourable to occupy by $\operatorname{Pr}[1,2]$ than the Cu site as suggested by Lytle et al. [6]. In this case Pr could affect the chains as well as the plains. A part of the doped Pr at $\mathrm{Y}$ site as $\mathrm{Pr}^{4+}$ fills up the holes in the $\mathrm{Cu}-\mathrm{O}$ planes necessary for superconductivity while the rest is sitting at the $\mathrm{Ba}$ site as $\mathrm{Pr}^{3+}$ which may be responsible for the magnetic pair-breaking. The XANES data show clearly that the valence of $\mathrm{Y}$ and Ba does not change at all. Small changes are seen in the pre-edge structure on the $\mathrm{Cu} \mathrm{K}$ edge indicating a shift towards $\mathrm{Cu}^{+}$at intermediate compositions. The presence of $\mathrm{Pr}$ at $\mathrm{Ba}$ site could be the reason for the observed $\mathrm{Cu}-\mathrm{O}$ coordinates at about $2.4 \AA$ (the apical oxygen for $\mathrm{Cu}$ ) to have compositional dependence. Our data exclude the possibility of some Pr substituting for $\mathrm{Cu}$, as suggested by Lytle et al. [6].

The presence of $\mathrm{Pr}$ in mixed valent state and occupying two different sites contributes to the suppression of superconductivity in 1-2-3 compounds containing $\operatorname{Pr}[2-5]$.

\section{Acknowledgments}

We are grateful to the UGC, New Delhi and EC (European Commission) for their financial support of this work. One of us (K.B. Garg) is also thankful to the CSIR for the Emeritus Scientist Fellowship.

\section{References}

[1] Khomskii D., J. Super. 6 (1993) 69.

[2] Blackstead H.A., Dow J.D., Phys. Rev. B 51 (1995) 11830.

[3] Han J.H., Gu C.X., Lim P.K., Sol. State Commun. 91 (1994) 901.

[4] Khaled M., Saini N.L., Garg K.B., Studer F., Sol. State Commun. (accepted, June 27, 1996).

[5] Khaled M. et al., XAFS IX, Grenoble, August 1996.

[6] Lytle F.W. et al., Phys. Rev. B 41 (1990) 8955. 